\title{
Determination of Sliced Pineapple Drying Characteristics in A Closed Loop Heat Pump Assisted Drying System
}

\author{
Cüneyt Tunçkala, Salih Coşkun ${ }^{\text {,** }}$, İbrahim Doymaz ${ }^{c}$, Enes Ergun ${ }^{d}$ \\ ${ }^{a}$ Yalova Community College, Electric and Energy Department, Air Conditioning And Refrigeration Technology Program, Yalova University, \\ 77100 Yalova, Turkey \\ $b^{b,}$ Vocational School of Technical Science, Electric and Energy Department, Air Conditioning and Refrigeration Technology Program, 16059 \\ Bursa, Turkey \\ 'Department of Chemical Engineering, Ylldız Technical University, 34210 Esenler, Istanbul, Turkey \\ 'Institute of Science, Uludag University, 16059 Görükle, Bursa, Turkey
}

\begin{abstract}
Pineapple (Ananascomosus) slices were dried with the aid of a heat pump assisted dryer (HPD). During this process, air velocity was kept constant at $1 \mathrm{~m} / \mathrm{s}$, while air temperatures were changed as $37^{\circ} \mathrm{C}, 40^{\circ} \mathrm{C}$ and $43^{\circ} \mathrm{C}$. The drying air was also circulated by using an axial fan in a closed cycle and fresh air was not allowed into the system. The drying rate and drying time were significantly influenced by drying temperature. It was observed that drying temperatures had significant effects on the drying rate and drying time. During the conduct of the study, pineapple slices were dried at 37 , 40 and $43^{\circ} \mathrm{C}$ for 465,360 and $290 \mathrm{~min}$, respectively. The specific moisture extraction ratio (SMER) values were observed to change as drying temperatures were changed. The drying rate curves indicated that the whole drying process occurred in the falling rate period. Seven well-known thin-layer models (Lewis, Henderson \&Pabis, Logarithmic, Page, Midilli \& Kucuk, Weibull and Aghbashlo et al.) were employed to make a prediction about drying kinetics through nonlinear regression analysis. The Midilli \& Kucuk and Aghbashlo et al. models were consistent with the experimental data. Fick's second law of diffusion was used to determine the moisture diffusivity coefficient ranging from $3.78 \times 10^{-9}$ to $6.57 \times 10^{-9} \mathrm{~m}^{2 / \mathrm{s}}$ the each of the above mentioned temperatures. The dependence of effective diffusivity coefficient on temperature was defined by means a fan Arrhenius type equation. The activation energy of moisture diffusion was found to be $75.24 \mathrm{~kJ} / \mathrm{mol}$.
\end{abstract}

Keywords: Heat pump, dryer, pineapple, drying, drying kinetics

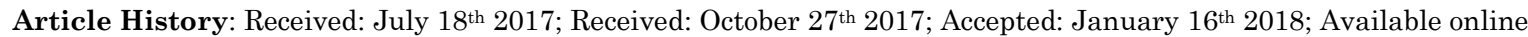
How to Cite This Article: Tunçkal, C., Coşkun, S., Doymaz, I. and Ergun, E. (2018) Determination of Sliced Pineapple Drying Characteristics in A Closed Loop Heat Pump Assisted Drying System. International Journal of Renewable Energy Development, $7(1), 35-41$.

https://doi.org/10.14710/ijred.7.1.35-41

\section{Introduction}

The pineapple (Ananascomosus) is a tropical plant with an edible multiple fruit consisting of coalesced berries, also called pineapples (Morton 1987; Omolola et al. 2017). Pineapples can be consumed fresh, cooked, juiced, or preserved. Drying is one of the oldest methods of preserving agricultural products by using heat and mass transfer. It has become necessary because most fruits are highly perishable owing to their high moisture content and the need to make them available all year round and at locations where they are not produced. In addition to preservation, the reduced weight and bulk of dehydrated products decreases packaging, handling and transportation costs (Omolola et al. 2017). There are many investigations on hot air drying, vacuum drying, freezing drying and heat pump drying (HPD) systems to improve drying quality and energy efficiency. The HPD system is the most advanced system because of lowest energy consumption (Colak and Hepbasli, 2009; Filho et al. 1996). According to numerous studies, color and flavor quality of agricultural products dried by using HPD system were better than products dried by using conventional dryer with hot air (Strommen et al. 1994; Prasertsan et al. 1998; Soponronnarit et al. 1998; Teeboonma et al. 2003). There are many studies about dried agricultural products such as kiwi, avocado, mango, papaya, apple, bananas, pepper, mushroom, tomato, herbs ginseng, echinace, carrot etc. by using HPD system(Coşkun et al. 2017, Aktas and Kara, 2013; Juan et al. 2013; Aktas et al. 2012; Ceylan 2009;Aktas et al. 2009; Aghbashlo et al. 2009 ; Pal et al. 2008; Teeboonma et al. 2003; Chua et al. 2001; Phani and Greg, 2005; Queiroz et al. 2004; Achariyaviriya et al. 2000; Soponronnarit et al. 1998; etc.) can be given as examples. 
Citation: Tunçkal, C., Coşkun, S., Doymaz, I. and Ergun, E. (2018) Determination of Sliced Pineapple Drying Characteristics in A Closed Loop Heat Pump Assisted Drying System. Int. Journal of Renewable Energy Development, 7(1),35-41, doi.org/10.14710/ijred.7.1.35-41

P a g e | 36

There are various studies about drying pineapple by using different drying methods including microwave-vacuum drying (Corrêa et al. 2011), hot-air drying (Agarry et al. 2013; Olanipekun 2015; Kingsly et al. 2009; Gujral et al. 2013; Ramallo and Mascheroni, 2012), and solar drying (Bala et al. 2003). But, there is no information in literature for drying of pineapple slices in the closed loop heat pump dryer. The purpose of this study was to investigate effect of drying air temperature on the drying behavior of pineapple slices, to fit the experimental data to seven thin-layer models, and to calculate the effective moisture diffusivity and activation energy of pineapple in the closed loop HPD system.

\section{Materials and Methods}

In this study, 600 g. pineapple slices with a thickness of $6 \mathrm{~mm}$ were dried employing a closed loop heat pump assisted dryer (HPD) system. A 5 gram sample of the pineapple slices were heated at $70^{\circ} \mathrm{C}$ for 18 min until the equilibrium moisture content was reached. The initial dry basis moisture content of the pineapple slices was measured to be $10.765 \mathrm{~g}$ water/g dry matter. The pineapple slices were dried until the moisture content reached $0.333 \mathrm{~g}$ water/g dry matter. The experiments were performed at $1 \mathrm{~m} / \mathrm{s}$ constant air velocity and three different drying chamber temperatures $\left(37,40\right.$ and $\left.43^{\circ} \mathrm{C}\right)$. HPD system is made up of a drying chamber, a heat pump, a circulating duct and a fan. Drying chamber has dimension of $0.60 \mathrm{~m}$ width, $0.60 \mathrm{~m}$ height and0.60 $\mathrm{m}$ length. The heat pump (HP) is composed of a compressor, a condenser, a metering device and two condensers. Refrigerant $134 \mathrm{a}$ is used in this system. During the process, the drying air was circulated in closed-loop by an axial fan and not allowed to let the fresh air in. In this system, firstly the drying air leaving from evaporator enters the internal condenser (E) where it absorbs heat from refrigerant and then enters the drying chamber (A) to dry the product. Second the humid and warm air leaving drying chamber (B) enters to evaporator to remove moisture (C). Third, dry and cold air leaving from evaporator (D) enters the internal condenser again to warm up. Thus the cycle continues. During the experiments, the drying chamber temperature was maintained at 37, 40 and $43^{\circ} \mathrm{C}$ using a thermostat which controlled two solenoid valves. One of them was placed at the bypass line, while the other was placed at the liquid line, as seen in Fig. 1. When the air temperature in drying chamber reached the set value, the solenoid valve at the liquid line closed, the other at the bypass line opened, so, the external condenser was also activated with the internal condenser. Measurement devices and their specifications are given in Table 2.

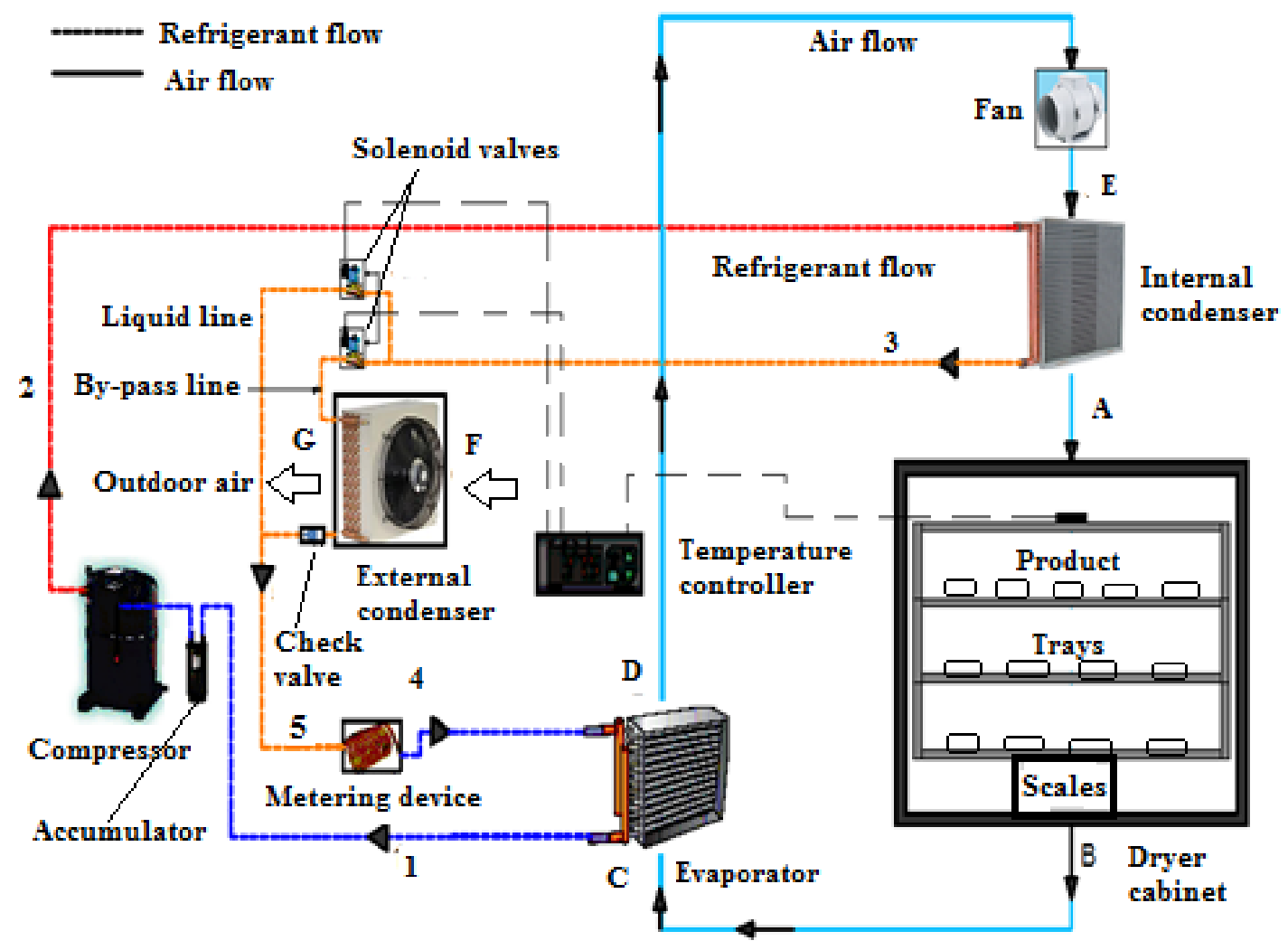

Fig. 1 Experimental set-up 
Table 1.

Technical specifications of heat pump components

\begin{tabular}{|c|c|}
\hline Components & Specifications \\
\hline Evaporator & Aluminum finned tube, $2.78 \mathrm{~m}^{2}$ \\
\hline $\begin{array}{l}\text { Metering device (capillary } \\
\text { tube) }\end{array}$ & 1 meter length, 0.0015 meter diameter \\
\hline Internal condenser & Aluminum finned tube, $3.60 \mathrm{~m}^{2}$ \\
\hline External condenser & Aluminum finned tube, $1.56 \mathrm{~m}^{2}$ \\
\hline Compressor & $\begin{array}{l}\text { Rotary type, cylinder volume, } 8.6 \mathrm{~cm}^{3} \text {, nominal power } 750 \\
\text { W. }\end{array}$ \\
\hline
\end{tabular}

Table 2.

Measurement devices

\begin{tabular}{llll}
\hline Measured quantities & Measurement devices & Measurement ranges & Accuracies \\
\hline Product mass & Electronic scale & $0-70 \mathrm{~kg}$ & $\pm 2 \mathrm{~g}$ \\
Air velocity & Rotating anemometer & $0.1-10 \mathrm{~m} / \mathrm{s}$ & $\pm 0.1 \mathrm{~m} / \mathrm{s}$ \\
Air temperature in drying chamber & Electronic thermostat & $(-50)-(+130)^{\circ} \mathrm{C}$ & $\pm 0.1^{\circ} \mathrm{C}$ \\
Temperature and relative humidity of & Hygro-thermometer & $0-100 \%$ & $\pm 2 \% \mathrm{RH}$ \\
air in air duct & Electronic manifold & $(-40)-(+80)^{\circ} \mathrm{C}$ & $\pm 0.4^{\circ} \mathrm{C}$ \\
Refrigerant pressures & Data logging thermometer & $(-50)-(+250)^{\circ} \mathrm{C}$ & $\pm 0.1 \mathrm{bar}$ \\
Refrigerant temperatures & Electrical power meter & $150-300 \mathrm{~V}$ & $\pm 0.5^{\circ} \mathrm{C}$ \\
Power consumptions & & & $0.5 \mathrm{~s} / \mathrm{day}$ \\
\hline
\end{tabular}

\section{Analysis}

\subsection{Mathematical Modeling of HPD System}

Performance of a dryer is commonly defined by specific moisture extraction ratio (SMER). It was calculated as follow,

$$
S M E R=\dot{m}_{w} / \dot{W}_{\text {total }}
$$

Here, $\dot{m}_{W}$ is amount of evaporated water from product, $\dot{W}_{\text {tatal }}$ is total energy input, which includes energy consumptions of compressor, inlet and outlet fans. Heat pump performance is also defined by coefficient of performance (COP). It was calculated as follow,

$$
C O P=\dot{Q}_{a} / \dot{W}_{\text {total }}
$$

Here, $\dot{Q}_{a}$ is amount of heat transferred to drying air.

\subsection{Mathematical Modeling of the Drying Curves}

In this study, seven common thin-layer drying models which is given in Table 3 were used to consistent with experimental data obtained at three different air temperatures of 37,40 and $43^{\circ} \mathrm{C}$ to describe drying characteristics of pineapple. The moisture content of pineapple slices was calculated by eq. (3)

$$
M=\left(W_{i}-W_{d}\right) /\left(W_{d}\right)
$$

Moisture ratio of pineapple slices was calculated by eq. (4)
$M R=\left(M_{t}-M_{e}\right) /\left(M_{0}-M_{e}\right)$

MR was simplified to $M_{t} / M_{0}$ instead of $\left(M_{t}-M_{e}\right) /$ $\left(M_{0}-M_{e}\right)$. Because the values of $M_{e}$ are too small to compared to $M_{t}$ or $M_{0}$ for a long period of time (Olimat 2017).

Table 3.

Drying models

\begin{tabular}{ll}
\hline Model names & Moisture Ratio (MR) \\
\hline Henderson \&Pabis & $M R=a \exp (-k t)$ \\
Lewis & $M R=\exp (-k t)$ \\
Page & $M R=\exp \left(-k t^{n}\right)$ \\
Logarithmic & $M R=a \exp (-k t)+c$ \\
Aghbashlo et al. & $M R=\exp [-(a t) /(1+b t)]$ \\
Midilli\&Kucuk & $M R=a \exp \left(-k t^{n}\right)+b t$ \\
Weibull & $M R=\exp \left(-\left(\frac{t}{b}\right)^{a}\right)$
\end{tabular}

$a, b, c, n, k$, empirical constants and coefficients in drying models

\subsection{Data Analysis}

The statistical analysis of the experimental data was performed by Statistica 8.0.550 sotfware (StatSoft Inc., Tulsa, OK, USA). Non-linear regression procedure based on the LevenbergMarquardt algorithm was used to predict the parameters of the models. To select most suitable drying model, some useful parameters, such as coefficient of determination $\left(R^{2}\right)$, reduced chisquare $\left(\chi^{2}\right)$ and root mean square error (RMSE) were used. These parameters were defined by using following equations: 
Citation: Tunçkal, C., Coşkun, S., Doymaz, I. and Ergun, E. (2018) Determination of Sliced Pineapple Drying Characteristics in A Closed Loop Heat Pump Assisted Drying System. Int. Journal of Renewable Energy Development, 7(1),35-41, doi.org/10.14710/ijred.7.1.35-41

P a g e | 38

$$
\begin{aligned}
& R^{2}=1-\left[\sum\left(M R_{p r e, i}-M R_{\exp \dot{ }}\right)^{2}\right] /\left[\sum_{i=1}^{N}\left(\overline{M R}_{p r e}-M R_{\exp \dot{ }}\right)^{2}\right] \\
& \chi^{2}=\sum_{i=1}^{N}\left(M R_{\exp \dot{i}}-M R_{p r e, i}\right)^{2} /(N-z)
\end{aligned}
$$

$$
R M S E=\left[\frac{1}{N} \sum_{i=1}^{N}\left(M R_{p r e, i}-M R_{\text {exp }, i}\right)^{2}\right]^{1 / 2}
$$

Higher $R^{2}$ and lower $\chi^{2}$ and $R M S E$ values indicate good fitness of the established model (Akpinar and Toraman, 2016).

\subsection{Determination of Effective Moisture Diffusivity and Activation Energy}

Fick's second law of diffusion equation, represented as a mass-diffusion equation for drying agricultural products in a falling rate period as shown in Eq. (8)

$$
\frac{\partial M}{\partial t}=\nabla\left[D_{e f f}(\nabla M)\right]
$$

Diffusion equation (Eq. 9) for slab geometry was solved by (Crank 1975), assuming uniform initial moisture distribution, constant diffusivity with negligible shrinkage and resistance:

$$
M R=\frac{8}{\pi^{2}} \sum_{n=0}^{\infty} \frac{1}{(2 n+1)^{2}} \exp \left(-\frac{(2 n+1)^{2} \pi^{2} D_{e f f} t}{4 L^{2}}\right)
$$

When the time increased, only the first term can be used to estimate the drying rate $(n=0)$, and then Eq. (10) converges into:

$$
M R=\frac{8}{\pi^{2}} \exp \left[\left(-\pi^{2} D_{e f f} t\right) /\left(4 L^{2}\right)\right]
$$

The values of effective moisture diffusivity $\left(D_{\text {eff }}\right)$ are determined by the slope of a straight line when $\ln$ $(M R)$ versus time is plotted from eq. (11):

$$
\text { Slope }=\left(\pi^{2} D_{\text {eff }}\right) /\left(4 L^{2}\right)
$$

An Arrhenius type equation is generally used to model the effect of temperature on the effective moisture diffusivity:

$$
D_{e f f}=D_{0} \exp \left[\left(-E_{a}\right) /(R(T+273.15))\right]
$$

\section{Results and Discussion}

\subsection{System Performance}

Experiments were performed at $23.1^{\circ} \mathrm{C}$ outdoor temperature and $50 \%$ relative humidity conditions. At the end of the experiments mean COP and SMER values obtained represented in Table 4 . The higher SMER values were obtained during about the first two hours, than SMER values decreased due to drying rate. The highest SMER value was obtained as $0.264 \mathrm{~kg} / \mathrm{kWh}$ at drying air

temperature of $43^{\circ} \mathrm{C}$, while the lowest value was obtained as $0.218 \mathrm{~kg} / \mathrm{kWh}$ at $37^{\circ} \mathrm{C}$.

It is clear that increase in drying air temperature caused a decrease in drying time. The drying time of samples decreased from $465 \mathrm{~min}$. to 290 min.as the air temperature was increased from $37^{\circ} \mathrm{C}$ to $43^{\circ} \mathrm{C}$. These results are consistent with the results of Marcel et al. (2013) and Olanipekun (2015) for pineapple slices.

Table 4.

Mean COP and SMER values

\begin{tabular}{ccc}
\hline $\begin{array}{c}\text { Drying } \\
\text { Temperature }\left({ }^{\circ} \mathrm{C}\right)\end{array}$ & COP $_{\text {mean }}$ & $\begin{array}{c}\text { SMER } \\
(\mathrm{kg} / \mathrm{kWh})\end{array}$ \\
\hline 37 & 2.988 & 0.218 \\
40 & 3.114 & 0.230 \\
43 & 3.259 & 0.264 \\
\hline
\end{tabular}

\subsection{Drying Curves}

Changing of moisture content with drying time for pineapple slices at 37,40 and $43^{\circ} \mathrm{C}$ is shown in Fig. 2.

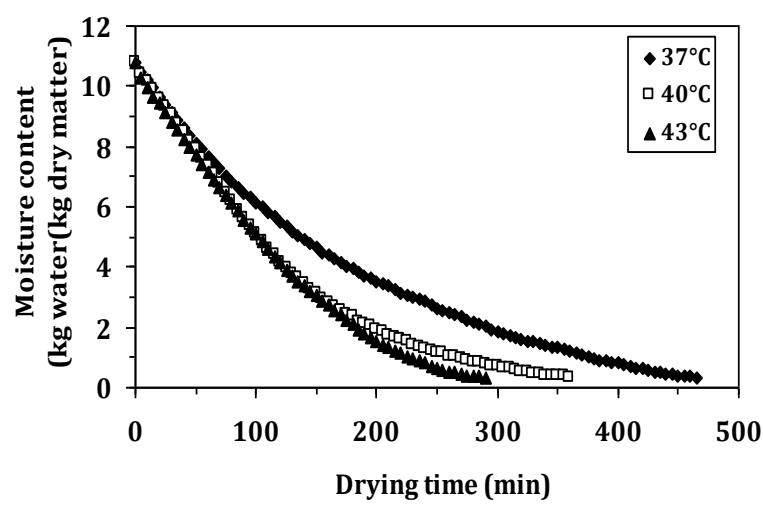

Fig. 2 Drying curves of pineapple slices

\subsection{Evaluation of Drying Models}

Non-linear regression analysis was applied in accordance with seven drying models listed in Table 5. The best mathematical model was chosen to fit the experimental data based on maximized $R^{2}$ and minimized $\chi^{2}$ and RMSE. The results of statistical analysis for several models were presented in Table 5 .

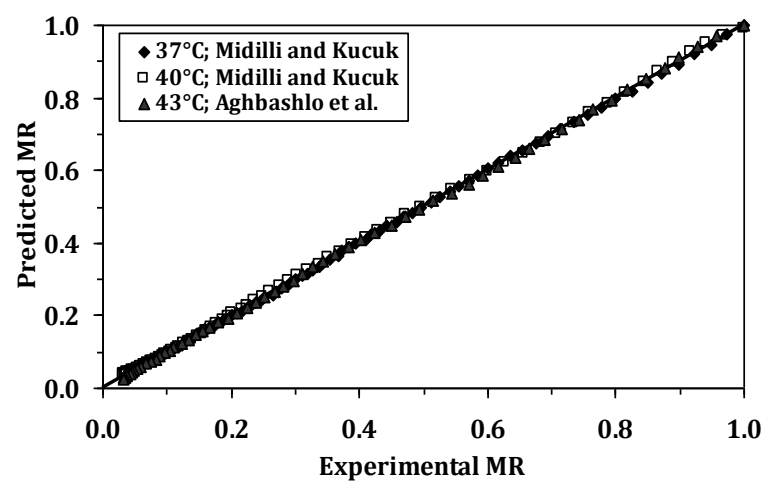

Fig. 3 The experimental MR versus the predicted MR for selected models 
At the end of analysis, it was shown that the predicted variables are consistent with the experimental results for some models. Especially, the model of Midilli \& Kucuk shows good agreement at drying air temperature of 37 and $40^{\circ} \mathrm{C}$, while the model of Aghbashlo et al. (2009) indicates good agreement at $43^{\circ} \mathrm{C}$, so these models could be used satisfactorily to estimate the drying kinetics of pineapple. The $R^{2}, \chi^{2}$ and $\mathrm{RMSE}$ values for the selected models change between 0.9976 and $0.9998,0.000009$ and 0.000203 and 0.024175 and 0.101808, respectively. Fig.3 shows the experimental data with the predicted ones using different models for pineapple slices at 37, 40 and $43^{\circ} \mathrm{C}$.

Table 5.

Statistical values of thin-layer drying of pineapple slices

\begin{tabular}{clccc}
\hline $\mathbf{T}$ & Model name & $\mathbf{R}^{2}$ & $\chi^{2}$ & RMSE \\
\hline \multirow{3}{*}{$37^{\circ} \mathrm{C}$} & Lewis & 0.9963 & 0.000264 & 0.126891 \\
& Henderson \& & 0.9967 & 0.000237 & 0.117119 \\
& Pabis & & & \\
& Logarithmic & 0.9995 & 0.000032 & 0.047444 \\
& Page & 0.9977 & 0.000162 & 0.098458 \\
& Weibull & 0.9978 & 0.000162 & 0.098457 \\
& Midilli \& Kucuk & 0.9998 & 0.000009 & 0.024175 \\
& Aghbashlo et al. & 0.9987 & 0.000091 & 0.076644 \\
& Lewis & 0.9875 & 0.001053 & 0.237945 \\
& Henderson \& & 0.9936 & 0.000549 & 0.163617 \\
$40^{\circ} \mathrm{C}$ & Pabis & & & \\
& Logarithmic & 0.9969 & 0.000268 & 0.109637 \\
& Page & 0.9995 & 0.000036 & 0.041289 \\
& Weibull & 0.9995 & 0.000035 & 0.041289 \\
& Midilli \& Kucuk & 0.9997 & 0.000026 & 0.037088 \\
& Aghbashlo et al. & 0.9976 & 0.000203 & 0.101808 \\
& Lewis & 0.9768 & 0.001718 & 0.277698 \\
& Henderson \& & 0.9834 & 0.001251 & 0.236054 \\
$43^{\circ} \mathrm{C}$ & Pabis & & & \\
& Logarithmic & 0.9980 & 0.000146 & 0.077452 \\
& Page & 0.9970 & 0.000224 & 0.098827 \\
& Weibull & 0.9970 & 0.000224 & 0.098828 \\
& Midilli \& Kucuk & 0.9994 & 0.000040 & 0.035910 \\
& Aghbashlo et al. & 0.9997 & 0.000019 & 0.025291 \\
\hline & & & & \\
\hline
\end{tabular}

\subsection{Effective Moisture Diffusivity and Activation Energy}

The effective moisture diffusivity $\left(D_{\text {eff }}\right)$ of pineapple slices was calculated by using Eq. (12) and it was obtained at drying air temperature of 37,40 and $43^{\circ} \mathrm{C}$ as $3.78 \times 10^{-9}, 5.37 \times 10^{-9}$ and $6.57 \times 10^{-9} \mathrm{~m}^{2} / \mathrm{s}$, respectively. As expected that the $D_{\text {eff }}$ values were observed rising depending on increase of drying air temperature. Increase in drying air temperature may be cause in greater absorption of moisture, that increases the moisture gradient between the product and ambient and that brings about an increase in the effective moisture diffusivity. Results obtained from this study for pineapple slices are similar to results of Olenipekun et al.
(2015). The $D_{\text {eff }}$ values must be within the normal range $10^{-12}-10^{-8} \mathrm{~m}^{2} / \mathrm{s}$ for drying of food materials (Zogzas et al. 1996). $D_{\text {eff }}$ values for pineapple slices obtained from this study are close to the values of $6.64 \times 10^{-7}$ to $12.93 \times 10^{-7} \mathrm{~m}^{2} / \mathrm{s}$ reported by Gujral et al. (2013) at different air temperatures. The differences between the results may be because of the structure of composition, shape and initial moisture content, besides the drying temperature, pre-treatments, and drying equipment. To calculate activation energy, a graph was plotted $\ln \left(D_{\text {eff }}\right)$ versus $(1 /(\mathrm{T}+273.15))$ as seen in Fig.4. The effect of temperature on $D_{\text {eff }}$ of the samples with following coefficients was determined by Eq. (13):

$$
\begin{aligned}
& D_{\text {eff }}=1.823 \times 10^{4} \exp [-(9050.6) /((T+273.15)] \\
& \left(\mathrm{R}^{2}: 0.9783\right)
\end{aligned}
$$

The activation energy of pineapple was calculated as $75.24 \mathrm{~kJ} / \mathrm{mol}$ by using Eq. (14).This value is in the range of $12.7-110 \mathrm{~kJ} / \mathrm{mol}$ for various foods reported by Zogzas et al. (1996). The similar value is proposed in the literature for drying of pineapple by Olanipekun et al (2015).

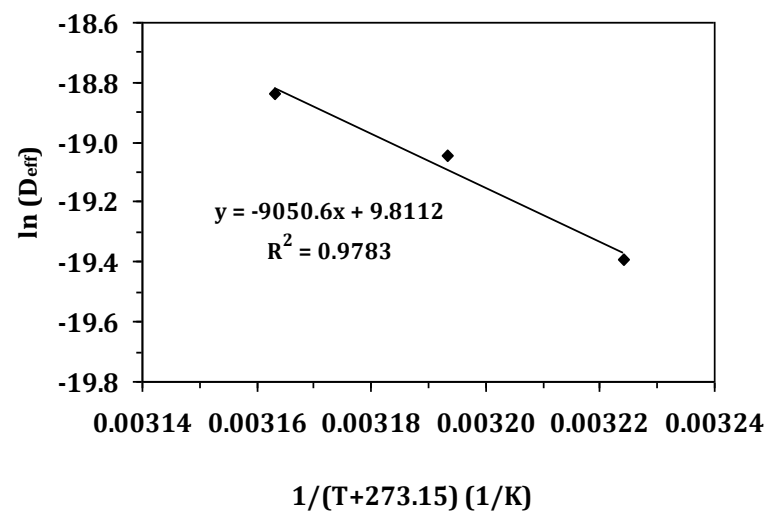

Fig. 4 Arrhenius-type relationship between effective moisture diffusivity and drying air temperature

\section{Conclusions}

Drying characteristics of pineapple slices dried by a closed loop HPD system at drying air temperature of 37,40 and $43^{\circ} \mathrm{C}$ were examined. Seven thinlayer drying models were applied and fitted to the experimental data to determine the drying kinetics of pineapple slices. Drying by a heat pump assisted dryer should be at as high a drying temperature as possible. Because, higher COP and SMER values were obtained at higher drying air temperatures. According to the results of regression analysis, the experimental data were well predicted by the Midilli \& Kucuk and Aghbashlo et al. models. Deff values of pineapple slices were obtained as the range of $3.78 \times 10^{-9}$ to $6.57 \times 10^{-9} \mathrm{~m}^{2} / \mathrm{s}$. Activation energy of pineapple was found as $75.24 \mathrm{~kJ} / \mathrm{mol}$. It is clearly seen that these results agree with data reported in literature.

Nomenclature

HPD heat pump drying,

SMER specific moisture extraction ratio, 
Citation: Tunçkal, C., Coşkun, S., Doymaz, I. and Ergun, E. (2018) Determination of Sliced Pineapple Drying Characteristics in A Closed Loop Heat Pump Assisted Drying System. Int. Journal of Renewable Energy Development, 7(1),35-41, doi.org/10.14710/ijred.7.1.35-41

$\mathrm{P}$ a g e | 40

$\dot{\mathrm{m}}_{\mathbf{w}} \quad$ amount of evaporated water from product,

M moisture content (g water/g dry matter),

COP coefficient of performance,

$\dot{Q}_{a} \quad$ amount of heat transferred to drying

$\mathrm{W}_{\mathrm{i}} \quad \begin{aligned} & \text { air, } \\ & \text { weight of sample }(\mathrm{g}),\end{aligned}$

$\dot{W}_{\text {total }} \quad$ total energy input,

$\mathrm{W}_{\mathrm{i}} \quad$ initial matter content of sample

(g),

$\mathrm{W}_{\mathrm{d}} \quad$ dry matter content of sample (g),

$\mathrm{M}_{0} \quad$ initial moisture content (g water/g dry matter),

$\mathrm{M}_{\mathrm{e}} \quad$ equilibrium moisture content (g water/g dry matter),

$\mathrm{M}_{\mathrm{t}} \quad$ the moisture content at $\mathrm{t}$ time ( $\mathrm{g}$ water/g dry matter),

$\mathrm{t} \quad$ drying time $(\mathrm{min})$,

$\mathrm{T} \quad$ temperature $\left({ }^{\circ} \mathrm{C}\right)$

$\mathrm{R}^{2} \quad$ correlation index,

$X^{2} \quad$ reduced chi-square,

RMSE root mean square error,

$\mathrm{a}, \mathrm{b}, \mathrm{c}, \mathrm{k}, \mathrm{n} \quad$ constants in the drying models,

$\mathrm{MR}_{\text {exp,i }} \quad$ experimental dimensionless moisture ratios,

$\mathrm{MR}_{\text {pre,i }} \quad$ predicted dimensionless moisture ratios,

$\mathrm{N}$ number of observations,

Z number of constants,

$\mathrm{D}_{\text {eff }} \quad$ effective moisture diffusivity $\left(\mathrm{m}^{2} / \mathrm{s}\right)$,

$\mathrm{L}$ the half-thickness of the slab in samples $(\mathrm{m})$,

$\mathrm{n} \quad$ positive integer,

$\mathrm{D}_{0} \quad$ pre-exponential factor $\left(\mathrm{m}^{2} / \mathrm{s}\right)$,

$\mathrm{E}_{\mathrm{a}} \quad$ activation energy $(\mathrm{kJ} / \mathrm{mol})$,

$\mathrm{R} \quad$ universal gas constant $(\mathrm{kJ} /(\mathrm{mol} \times \mathrm{K}))$,

$\mathrm{T}$ temperature $\left({ }^{\circ} \mathrm{C}\right)$,

\section{References}

Achariyaviriya S., Sopanronnarit S and Terdyothin A. (2000) Mathematical Model Development and Simulation of Heat Pump FruitDdryer. Drying Technology, 18 (1,2), 479-591.

Agarry S.E., Ajani A.O and Aremu M.O. (2013) Thin Layer Drying Kinetics of Pineapple: Effect of Blanching Temperature-Time Combination. Nigerian Journal of Basic and Applied Science, 21, 1-10.

Aghbashlo M., Kianmehr M.H., Khani S and Ghasemi M. (2009) Mathematical Modeling of Carrot Thin-Layer Drying Using New Model. International Agrophysics, 23, 313-317.

Akpinar E. K and Toraman S. (2016) Determination of Drying Kinetics and Convective Heat Transfer Coefficients of Ginger Slices. Heat and Mass Transfer, 52, 2271-2281.

Aktas M and Kara M. Ç. (2013) Güneş Enerjisive Isı Pompalı Kurutucuda Dilimlenmiş Kivi Kurutulması. Journal of the Faculty of Engineering and Architecture of Gazi University 28, 733-741.

Aktas M., Sevik S., Doğan H and Ozturk M. (2012) Fotovoltaikve Termal Günes Enerjili Sürekli Bir Kurutucuda Domates Kurutulması. J of Agri. Sci, 18, 287- 298.

Aktas M., Ceylan I and Yılmaz S. (2009) Determination of Drying Characteristics of Apples in a Heat Pump and Solar Dryer. Desalination, 239, 266-275.

Bala B. K., Mondol M. R. A., Biswas, B. K., DasChowdury B. L and Janjai S. (2003) Solar drying of pineapple using solar tunnel drier. Renewable Energy 28 (2003), 183 190.

Ceylan I. (2009) Energy Analysis of PID Controlled Heat Pump Dryer. Engineering, 1, 188-195.

Chua K., Mujumdar A., Hawlader M., Chou S and Ho J. (2001) Batch Drying of Banana Pieces-Effect of Stepwise Change in Drying Air Temperature on Drying Kinetics and Product Colour. Food Research International, 34, 721-731.

Colak N and Hepbasli A. (2009) A Review of Heat Pump Drying part 1- Systems Models and Stuides. Energy conversion and Management, 50, 2180-2186.

Coşkun S, Doymaz, İ., Tunçkal, C., Erdoğan S. (2017) Investigation of drying kinetics of tomato slices dried by using a closed loop heat pump dryer. Heat and Mass transfer, 53, 1863-1871.

Corrêa J.L.G., Dev S.R.S., Gariepy Y and Raghavan, G.S.V. (2011) Drying of Pineapple by Microwave-Vacuum with Osmotic Pretreatment. Drying Technology, 29, 15561561.

Crank J, (1975) The Mathematics of Diffusion. Oxford: Clarendon Press,.

Filho O. A and Strommen I. (1996) The Application of Heat Pump in Drying of Biomaterials. Drying Technology, 14(9), 2061-2090.

Gujral H. S., Oberoi D. P. S., Singh R., Gera M. (2013) Moisture Diffusivity During Drying of Pineapple and Mango Leather as Affected by Sucrose, Pectin, and Maltodextrin. International Journal of Food Properties, 16, 359-368.

Juan W., Chong Z., Zhentao Z and Luwei Y. (2013) Performance Analysis of Heat Pump Dryer to Dry Mushroom. Advanced J. of Food Sci. and Technology, 5 (2), 164-168.

Kingsly A. R. P., Balasubramaniam, V. M and Rastogi, N. K. (2009) Effect of high-pressure processing on texture and drying behavior of pineapple. Journal of Food Process Engineering, 369-381.

Marcel E., Tchamye B., Alexis K and François G. (2013) Optimization of the Design and Drying Process Adapted to Pineapple Slices. Journal of Food Science and Engineering, 3, 609-615.

Morton, JF, (1987) Pineapple, Ananascomosus. Retrieved,2011-04-22.

Olanipekun B. F. (2015) Mathematical Modeling of ThinLayer Pineapple Drying. Journal of Food Processing and Preservation, 39,1431-1441.

Olanipekun B. F., Tunde-Akintunde T. Y., Oyelade O. J., Adebisi M. G and Adenaya T. A. (2015) Mathematical Modeling of Thin-Layer Pineapple Drying. Journal of Food Processing and Preservation, 39,1431-1441.

Olimat, A.N. (2017) Study of Fabricated Solar Dryer of Tomato Slices Under Jordon Climate Condition. International Journal of Renewable Energy Development, 6(2), 93-101.

Omolola, A.O.,Jideani, I.O., Patrick F and Kapila, P.F.(2017) Quality Properties of Fruits as Affected by Drying Operation. Critical Reviews in Food Science and Nutrition, 57, 95-108.

Pal U.S., Khan M.K and Mohanty S.N. (2008) Heat Pump Drying of Green Sweet Pepper. Drying Technology, 26: 1584-1590.

Phani K. A and Greg J. S. (2005) Re-circulating Heat Pump Assisted Continuous Bed Drying and Energy Analysis. International Journal of Energy Research, 29, 961-972.

Prasertsan S and Saen-Saby P.(1998) Heat Pump Drying of Agricultural Material. Drying Technology, 16 (1,2), 235250.

Queiroz R., Gabas A.L and Telis V.R.N. (2004) Drying Kinetics of Tomato by Using Electric Resistance and Heat Pump Dryers. Drying Technology 22, 1603-1620.

Ramallo L. A and Mascheroni R.H. (2012) "Quality evaluation of pineapple fruit during drying process". Food and Bioproducts Processing, 90, 275-283.

Soponronnarit S., Nathakaranakule, A., Wetchacama S., Swasdisevi, T and Rukprang P.(1998) Fruit Drying 
Using HeatPump. RERIC International Energy Journal, 20, 38-53.

Strommen I and Kramer K.(1994) New Applications of Heat Pumps in Drying Processes. Drying Technology, 12(4), 889-901.

Teeboonma U., Tiansuwan J and Soponronnarit S.(2003) Optimization of Heat Pump Fruit Dryers. Journal of Food Eng, 59,369-377.

Zogzas N. P., Maroulis Z. B and Marinos-Kouris D.(1996) Moisture Diffusivity Data Compilation in Food stuffs. Drying Technology, 14, 2225-2253. 